\title{
CUA guideline on the evaluation and medical management of the kidney stone patient - 2016 update
}

\author{
Marie Dion, MD;1 Ghada Ankawi, MD; ${ }^{2}$ Ben Chew, MD, ${ }^{3}$ Ryan Paterson, MD, ${ }^{3}$ Nabil Sultan, MD; ${ }^{2}$ \\ Patti Hoddinott, MD;1 Hassan Razvi, MD'
}

'Division of Urology, Schulich School of Medicine and Dentistry, Western University, London, ON, Canada; ${ }^{2}$ Division of Nephrology, Schulich School of Medicine and Dentistry, Western University, London, ON, Canada; ${ }^{3}$ Department of Urological Sciences, University of British Columbia, Vancouver, BC, Canada

Cite as: Can Urol Assoc J 2016;10(11-12):E347-58. http://dx.doi.org/10.5489/cuaj.4218 Published online November 10, 2016.

\section{Introduction}

Despite technological advances in the surgical management of upper tract urinary stone disease that have significantly reduced patient morbidity and recovery time, new stone formation and recurrence remain significant health issues. Data from the U.S. National Health and Nutrition Examination Survey (NHANES) published in 2012 noted a kidney stone prevalence of $10.6 \%$ in men and $7.1 \%$ among women. ${ }^{1}$ Comparing these results to a similar survey conducted between 1976 and 1994, the overall prevalence of stone disease in the U.S. population has increased from 5.2 to $8.2 \% .^{2}$ An increase in stone formation, particularly among women, has also been observed such that the male:female ratio appears to be decreasing. ${ }^{3,4}$ Recent evidence also suggests there may be an increase in the incidence of certain stone compositions, such as uric acid, a type of stone clearly linked to both dietary and metabolic risk factors. ${ }^{5}$

Recurrence rates after an initial symptomatic stone event are reported to be from $30-50 \%$ within 10 years of first presentation. ${ }^{6,7}$ Patients are, therefore, generally motivated to explore prevention strategies. ${ }^{1}$ Studies have shown, however, that patients are more willing to undergo metabolic evaluation compared to physicians' willingness to further investigate them. ${ }^{8}$ Epidemiological data from the U.S. show that only $7 \%$ of patients with a high risk of recurrent stone disease undergo metabolic evaluation by any physician. ${ }^{9}$ The odds of undergoing metabolic evaluation were 2.9 and 3.9 times higher if patients were seen by a nephrologist or urologist, respectively. Bensaleh et al noted that $81 \%$ of patients interviewed would prefer to take a prophylactic medication than undergo another stone episode, and $92 \%$ of respondents preferred medication to undergoing surgery. ${ }^{8}$ In summary, the vast majority of stone patients would benefit from metabolic evaluation, but are not being investigated.
The economic burden of recurrent stone disease is also significant. Estimates of direct costs to care for and treat patients with stones and the indirect costs related to lost work time exceed $\$ 5$ billion USD. ${ }^{10,11}$ The observed increases in healthcare expenditures associated with nephrolithiasis are likely due to the increasing prevalence ${ }^{12}$ and procedure-related costs, despite a shift towards outpatient treatment, shorter length of hospital stay, and more minimally invasive procedures. ${ }^{11}$ Given the rising rates of obesity and diabetes and their association with stone formation, the cost of managing stone disease is expected to increase to 1.24 billion dollars yearly in the U.S. by $2030 .{ }^{13}$ Clearly, the need for stone prevention in those at risk will continue to have an important role.

In 2010, the Canadian Urological Association (CUA) Guidelines Committee commissioned the development of a clinical practice guideline on the evaluation and medical management of patients with upper tract urolithiasis. The aims of the guideline were to help clinicians identify patients at heightened risk of stone recurrence, to outline the required investigations to assess these patients, and to provide up-to-date advice on dietary and medical interventions of proven benefit in the Canadian context. In accordance with the CUA's policy of reviewing the content of guidelines every five years, this topic was felt to be ready for revision to reflect new advances in the preventative management of patients with renal stones. It should be noted that this guideline addresses the evaluation and medical prophylaxis of upper tract stones and not stones forming within the bladder.

\section{Literature review}

The content included in this document was obtained from a review of the English language literature. Management recommendations were based, whenever possible, on the most current literature since the last CUA guideline was published in 2010. A PubMed search was conducted encompassing the period from January 1, 2005 to July 1, 2015 to include the following terms in either the title or abstract: "nephrolithiasis," "urolithiasis," "kidney stone," "renal stone," and 
"urinary stone." In total, 4603 article titles were reviewed and 698 were identified as potentially relevant for inclusion in the literature assessment for this guideline. In addition, all references from recently published guidelines were assessed and relevant studies were included in our literature review.

Studies were evaluated and recommendations made based on Oxford levels of evidence and grades of recommendation as per the CUA's Guidelines Committee's directive. Guideline statements with management recommendations were developed based on the highest level of evidence.

\section{Indications for metabolic evaluation}

It is generally accepted that even the first time stone-former, without any identifiable risk factors for recurrent stone formation, should undergo a limited metabolic evaluation to rule out potential systemic disorders, such as hyperparathyroidism and renal dysfunction. This evaluation should include a urinalysis \pm culture, serum electrolytes $(\mathrm{Na}, \mathrm{K}, \mathrm{Cl}$, $\mathrm{HCO}_{3}$ ), serum $\mathrm{Ca}$, and serum creatinine (Level of Evidence 4, Grade C Recommendation).

An in-depth metabolic investigation may be considered for any patient who is interested and willing to participate in the endeavor to collect and analyze a 24-hour urine study and have blood work drawn, and is willing to alter his/ her diet or begin pharmacotherapy. There are, however, patient populations with clearly known risk factors where an in-depth metabolic investigation is highly recommended (Level of Evidence 3, Grade C Recommendation): ${ }^{14-20}$

- Children $(<18$ years of age)

- Bilateral or multiple stones

- Recurrent stones (having had two or more kidney stone episodes in the past)

- Non-calcium stones (e.g., uric acid, cystine)

- Pure calcium phosphate stones

- Any complicated stone episode that resulted in a severe (if even temporary) acute kidney injury, sepsis, hospitalization, or complicated hospital admission

- Any stone requiring percutaneous nephrolithotomy treatment

- Stones in the setting of a solitary (anatomical or functional) kidney

- Patients with renal insufficiency

- History of kidney stones and systemic disease that increases the risk of kidney stones (e.g., gout, osteoporosis, bowel disorders, hyperparathyroidism, renal tubular acidosis, etc.)

- Occupation where public safety is at risk (e.g., pilots, air traffic controller, police officer, military personnel, firemen)

Due to the infectious nature and cause of struvite stones, routine metabolic evaluation of patients with struvite stones is not usually recommended; however, routine urine culture and radiological investigations are necessary in this patient population.

In-depth evaluation

For those patients where an in-depth evaluation is indicated, the workup should include serum and 24-hour urine tests, as well as a thorough dietary history. These tests should include:

a) Serum:

- Creatinine, sodium, potassium, chloride, calcium, albumin, uric acid, bicarbonate

- Parathyroid hormone (PTH) level if serum calcium is high normal or abnormally elevated

- Vitamin D if low normal serum calcium or elevated serum PTH

b) 24-hour urine collection:

- Volume, creatinine, calcium, sodium, potassium, oxalate, citrate, uric acid, magnesium

- Cystine if suspect cystine stone or if the stone analysis is cystine

c) Spot urine:

- Urine $\mathrm{pH}$

- Urinalysis

- Specific gravity

Number of 24-hour urine collections

There is some controversy regarding the number of 24-hour urine collections necessary to investigate patients. ${ }^{21,22}$ Recent data suggests that up to $47.6 \%$ of patients had their clinical management changed by an abnormality that was identified only when two samples were collected. ${ }^{23,24}$ It is currently recommended that two 24-hour urine collections be obtained in order to correctly identify metabolic abnormalities. The benefit of two collections should be balanced, however, by the practicality and importance of obtaining at least one collection (Level of Evidence 3, Grade C Recommendation).

\section{Importance of stone analysis}

Identification of stone composition will aid in determining prevention and directing surgical options for future stones. Furthermore, identification of struvite, ammonium urate, uric acid, calcium phosphate, or cystine stones would alter whether or not 24-hour urine tests are required. Efforts should, therefore, be made to have patients collect stones they have passed or if stones are removed at the time of surgical intervention, they should be submitted for analysis (Level of Evidence 3, Grade C Recommendation).

If a patient continues to form new stones, it is worthwhile to repeat a stone analysis of the patient's subsequent stones. Stone composition changed in $21.2 \%$ of patients over time. Patients interchanged between calcium oxalate and calcium 
phosphate stones, and some uric acid stone-formers became calcium oxalate stone-formers. ${ }^{25}$

\section{General dietary measures}

Basic dietary and fluid intake advice has been shown to be effective in reducing stone recurrence rates and seems warranted for even the first-time stone-former without identifiable risk factors. The "stone clinic effect" first described by Hosking et al is a well-known phenomenon whereby counselling on appropriate fluid intake to avoid dehydration and dietary excesses can significantly reduce stone recidivism. ${ }^{26}$

The involvement of a registered dietician, if available in the counselling of patients with recurrent renal stones, should be incorporated into the management of these patients. In a retrospective review of 137 kidney stone patients with abnormalities on their 24-hour urine collection, after assessment and specific recommendations were made by a registered dietician, significant improvements were noted in urine volume, sodium, calcium, uric acid, citrate, and oxalate. ${ }^{27}$ Assessment with a registered dietician is strongly suggested where there is a history of compromised nutritional status, complex medical situations, patients with deficient nutrition knowledge, dietary risk cannot be completely assessed by the urologist, or for anyone who needs assistance implementing dietary recommendations..$^{28,29}$ Evidence suggests that patients who received specific dietary recommendations based on a comprehensive evaluation had fewer stone recurrences over three years than those who only received general dietary advice. ${ }^{30}$

The majority of studies evaluating the effect of dietary measures on stone prevention are based on retrospective cohort analyses. Confounding the results of some trials is the fact that several dietary measures are assessed simultaneously. Summarized below are the results of relevant studies based on the specific dietary component.

\section{Fluid intake}

Increasing water intake has been repeatedly shown to decrease stone risk substantially in many large cohort studies in men and women. ${ }^{31-35}$ In a meta-analysis of randomized controlled trials (RCTs) and observational studies on fluid intake, the risk reduction was in the range of $60-80 \%{ }^{36}$ Low urine volume was found to be a significant risk factor for recurrent stone disease in patients with idiopathic calcium stones and large fluid intake is suggested as the initial therapy for prevention of stone recurrences. ${ }^{37}$

The recommendation of fluid intake between $2.5-3 \mathrm{~L}$ or a urine output of $2.5 \mathrm{~L}$ is based on a meta-analysis of two trials where water intake of $2 \mathrm{~L}$ per day or fluid intake sufficient to produce $2.5 \mathrm{~L}$ of urine reduced stone risk by $61 \% .{ }^{38-40}$ Recent investigators have found weight- and urine calcium-based volume recommendations may be more efficient in reducing hypercalciuria in all patients and this is a consideration for urologists treating stone disease. ${ }^{41}$

Results on the protective effects of including fluids other than water in the diet are conflicting. Soft drinks, caffeinated beverages (such as coffee and tea), and alcohol have all been shown to have either some or no benefit in various trials. ${ }^{42-47}$ Restriction of these fluids is not necessary as long as a good amount of the patient's fluid intake consists of water. Lemonade is a dietary source rich in citrate and has been demonstrated to increase urinary citrate and urine volume. ${ }^{48}$ The addition of citrate-containing fluids may be of additional benefit in the prevention of nephrolithiasis.

As part of the prevention discussion with patients regarding appropriate fluid consumption, the clinician should explore barriers as to why increasing fluid intake may be difficult. This might include a lack of knowledge regarding what is appropriate fluid intake or the importance of compensating for large insensible fluid losses, patients' dislike of the taste of water, occupational barriers to fluid access, and urinary voiding difficulties. ${ }^{49}$

Recommendation: All stone-formers should be counselled to achieve a daily urine output of $2.5 L$ (Level of Evidence 2, Grade B Recommendation).

\section{Calcium}

There is still a public misconception that patients with stone disease should restrict calcium in the diet. On the contrary, numerous studies have shown that patients with higher calcium intake have a reduced risk of stone formation compared to those with low calcium intake. In a large prospective cohort of men, calcium intake was measured and high intake was inversely correlated with kidney stone risk (relative risk [RR] 0.56). ${ }^{32}$ In another large prospective cohort study of men, the relative risk of stone formation for highest and lowest quintiles of calcium intake was $0.69 .^{50}$ Higher calcium intake decreased the risk of stones in women by up to $28 \%$ in a prospective cohort study. ${ }^{31}$

In a large prospective cohort of women, dietary calcium was compared to supplemental calcium. The women in the highest quintile of dietary calcium had significantly lower risk; however, risk was slightly increased in women who took supplemental calcium. ${ }^{33}$ This may have been attributed to the timing of administration of calcium supplements since they were not consumed at mealtimes, which may have decreased its ability to chelate oxalate. Contrarily, another study of 96000 young females found calcium was again associated with reduced risk of stones, but supplemental calcium was not associated with increased risk. ${ }^{34}$

The recommended daily intake of calcium is 1000-1200 mg separated into two doses and ideally with meals. Calcium 
would ideally be obtained through diet, as some studies suggest supplementation may increase cardiovascular risk. ${ }^{51}$ Where supplementation is required, calcium supplementation taken with meals is suggested, as this results in the greatest oxalate sequestration and is not associated with an increased risk of hypercalciuria. ${ }^{52}$

Data regarding the relative merits of calcium citrate vs. calcium carbonate formulations are conflicting. There are no high-quality comparative trials to indicate one calcium preparation is superior. Calcium citrate may be associated with improved absorption when not taken with meals or in those patients with impaired gastric acid secretion. ${ }^{53,54}$ Both formulations have been shown to reduce urinary oxalate levels when taken with meals. ${ }^{55}$

\section{Recommendations:}

1. The goal for dietary calcium intake should be 1000-1200 mg/day (Level of Evidence 3, Grade C Recommendation).

2. Should calcium supplementation in a patient with calcium oxalate stone disease be required, calcium supplementation should be taken at mealtimes (Level of Evidence 3, Grade C Recommendation).

\section{Vitamin D}

The role of vitamin D depletion in the development of urinary stone disease is not entirely clear and results from studies examining the impact of low vitamin D and vitamin D supplementation on stone disease are conflicting. The prevalence of vitamin D insufficiency in patients at a Canadian metabolic stone clinic was $80.2 \% .{ }^{56}$ In other stone populations, inadequate vitamin D was noted in one-third of 236 recurrent calcium stone-formers. ${ }^{57}$

Many studies have examined the association between low bone mineral density, osteopenia, osteoporosis, fracture risk, and calcium nephrolithiasis. Patients with renal stones have associated low bone mineral density in several studies, with increasing risk correlating with increasing levels of hypercalciuria. ${ }^{58-60}$ In a large retrospective cohort of over 50000 patients and controls, nephrolithiasis was associated with fractures, with hazard ratios as high as $1.55 .{ }^{61} \mathrm{In}$ assessment of patients with first-time or recurrent stones, a high prevalence of osteoporosis and osteopenia was noted particularly in patients with vitamin D deficiency. ${ }^{62}$

Calcium stone-formers were found to have a blunted PTH response on a low-calcium diet, resulting in decreased bone density. ${ }^{63}$ Hyperparathyroidism was detected in $26 \%$ of patients and $91 \%$ of these were secondary to inadequate vitamin D. Patients with inadequate vitamin D had an increased number of metabolic abnormalities as compared to patients with normal vitamin D levels. ${ }^{56}$

Studies are conflicting when vitamin D levels were compared to urinary calcium excretion. Some studies noted an association between higher vitamin D levels and hypercalciuria, ${ }^{57,64}$ whereas other studies did not note an association between vitamin $\mathrm{D}$ and hypercalciuria ${ }^{65}$ or stone reccurrence. ${ }^{66}$

The impact of vitamin D supplementation on hypercalciuria and stone risk has also been assessed by multiple conflicting studies. In a retrospective review of 34 patients with stone disease, vitamin D and calcium were supplemented due to vitamin D insufficiency. Urinary calcium excretion with supplementation increased significantly (3.8 to $5.6 \mathrm{mmol} / \mathrm{d}$ ) and $23.5 \%$ developed de novo hypercalciuria. Over 39 months median followup, $50 \%$ of patients developed stones compared to $11 \%$ of non-hypercalciuric patients. ${ }^{67}$ In a study of over 46000 post-menopausal women aged 50-79 years randomized to calcium $1000 \mathrm{mg}$ and 400 IU of vitamin D or placebo, there was an increased risk of nephrolithiasis, with a hazard ratio of $1.17 .{ }^{68}$ The authors reported within the treatment group a small improvement in hip bone density, but no reduction in hip fractures, although when adherence to study protocol was considered, a reduction in hip fracture of $29 \%$ was seen. ${ }^{68}$

Other investigators have found vitamin D replenishment in patients with a history of nephrolithiasis does not impact hypercalciuria or stone risk. In patients with vitamin D insufficiency, calcium excretion did not change with vitamin D repletion based on 24-hour collections, and in some patients, it decreased. ${ }^{69} \mathrm{~A}$ randomized, double-blind, placebo-controlled study of high doses of vitamin D daily did not change urinary calcium excretion in healthy volunteers. ${ }^{70}$ Further investigators randomized 163 patients to vitamin D vs. placebo. Calcium intake was monitored and supplementation used to achieve total intake of $1200 \mathrm{mg}$ daily. Urine and serum calcium levels were monitored. Hypercalciuria was not associated with vitamin D intake. ${ }^{71}$ In a small prospective cohort of stone patients with low vitamin D levels, vitamin D repletion did not translate to increased mean calcium excretion. A subset of patients had increased urinary calcium, along with increased urinary sodium likely reflective of dietary variability. ${ }^{72}$ In a study of 53 post-menopausal women without a history of kidney stones, one year of supplementation with $1000 \mathrm{mg}$ of calcium and $400 \mathrm{IU}$ of vitamin D did not change urinary calcium excretion. ${ }^{73}$

Recommendation: In calcium oxalate stone-formers with documented vitamin $D$ deficiency, repletion is appropriate, but monitoring for hypercalciuria on 24-hour urine in followup is suggested (Level of Evidence 2-3, Grade C Recommendation).

\section{Animal protein}

In some populations, high animal protein was associated with a slight increase in the risk of nephrolithiasis. ${ }^{50}$ When men were randomized to a diet with reduced animal protein (52 g/day) and sodium (50 mmol/day) with normal calcium 
intake, this resulted in fewer stone episodes than a reduced calcium diet. ${ }^{74}$ In a large prospective cohort of men, dietary protein was directly associated with the risk of stone formation (RR 1.33). ${ }^{32}$ In a prospective trial of idiopathic calcium stone-formers and controls, dietary records indicated increased consumption of protein (animal and vegetable) and purine-rich foods in stone-formers. Urinary oxalate and calcium were higher and citrate lower in the stone-forming group, while uric acid was similar. Animal protein affected urinary oxalate only minimally. ${ }^{75}$ In another study, calcium and uric acid levels in urine were increased with dietary intake of protein. ${ }^{76}$

Other studies did not find a strong correlation between animal protein intake and risk of nephrolithiasis. Ninety-nine patients with calcium oxalate stones were randomized to low-protein, high-fiber diet vs. no intervention. All patients were instructed to increase fluid intake and maintain a diet adequate in calcium. The patients in the low-protein, highfiber diet group had increased stone formation compared to the control group. ${ }^{77}$ In other large dietary cohort studies, animal protein intake failed to demonstrate increased risk of stones in women. ${ }^{31,34}$

A diet high in animal protein was found to be associated with increased excretion of undissociated uric acid due to a reduction in urinary $\mathrm{pH}$, as well as a reduction in citrate excretion, predisposing these individuals to uric acid nephrolithiasis. ${ }^{78} \mathrm{~A}$ vegetarian diet has been demonstrated to reduce the risk of uric acid crystallization by $93 \%$ compared to a typical Western diet. $^{79}$

Different types of animal protein were compared in a randomized crossover study in 15 healthy volunteers using beef, chicken, and fish. Fish had high purine content and resulted in increased urinary uric acid excretion. Beef intake resulted in the highest saturation of calcium oxalate compared to chicken, but was similar to fish. ${ }^{80}$

Recommendation: In patients with recurrent calcium oxalate and uric acid nephrolithiasis, moderation of animal protein intake and avoidance of purine rich foods is suggested (Level of Evidence 2-3, Grade C Recommendation).

\section{Sodium}

When the urinary excretion levels of patients with idiopathic hypercalciuria were compared to those with normocalciuria, patients with hypercalciuria were found to have higher urinary sodium and sodium intake. ${ }^{81}$ In a randomized trial comparing low-calcium diet to low-sodium and animal protein, the low-sodium and animal protein diet resulted in fewer stone recurrences. ${ }^{74}$ High sodium intake was associated with up to $61 \%$ increase in stone risk in a large prospective cohort of women. ${ }^{31}$ In a randomized trial of 210 patients with hypercalciuria and calcium stones, a low-sodium diet resulted in lower urinary sodium, as well as lower urinary calcium and oxalate excretion and resulted in normalization of urine calcium excretion for one-third of patients. ${ }^{82}$

Recommendation: Patients with recurrent calcium nephrolithiasis should aim for sodium intake of $1500 \mathrm{mg}$ daily and not exceed $2300 \mathrm{mg}$ daily (Level I-2 evidence, Grade B Recommendation).

\section{Fruits and vegetables}

Low dietary intake of fiber, fruit, and vegetables increases the risk of kidney stones in women..$^{83}$ In another populationbased study, high dietary fruit intake was shown to decrease stone risk. ${ }^{84}$ In a small cohort of patients, eliminating fruits and vegetables from the diet resulted in decreased urine potassium, magnesium, citrate, and increased urine calcium. In 26 stone-forming patients with hypocitraturia, introducing these foods resulted in increased excretion of citrate, potassium, and magnesium and reduction in the saturation of calcium oxalate and calcium phosphate..$^{85}$

Recommendation: For kidney stone patients, a diet high in fiber, fruits, and vegetables may offer a small protective effect against stone formation (Level of Evidence 2-3, Grade C Recommendation).

\section{Vitamin C}

In population-based studies, intake of over $1000 \mathrm{mg}$ of vitamin $C$ daily caused a slight increase in the risk of nephrolithiasis. ${ }^{50,59}$ Vitamin $C$ supplementation of $1-2 \mathrm{~g}$ was associated with increased urinary oxalate in stone-forming patients. ${ }^{86,87}$ It is theorized that the excess vitamin $\mathrm{C}$ is converted to oxalate.

Recommendation: Vitamin C supplementation of more than $1000 \mathrm{mg}$ daily is not recommended due to the associated risk of hyperoxaluria and nephrolithiasis (Level Evidence 2-3, Grade C Recommendation).

\section{Specific prophylaxis based on stone composition}

In the following section, "index patients" have been created based on the predominant stone composition. Potential metabolic abnormalities will be described and specific diet and medical interventions will be highlighted for each clinical scenario.

Index patient 1: Calcium oxalate or mixed calcium oxalate/calcium phosphate stone

Patients with calcium oxalate or combined calcium oxalatecalcium phosphate stones may have normal 24-hour urine testing, hypercalciuria, hyperoxaluria, hypocitraturia, hyperuricosuria, low urine volume, or a combination of any of these features. ${ }^{88}$ All patients should be counselled regard- 
Dion et al.

ing previously described general dietary recommendations. Based on 24-hour urine results, the following interventions can be considered (Fig. 1).

\section{Thiazide diuretics}

Thiazide diuretics have been investigated in a number of studies for kidney stone prevention. In patients with recurrent calcium stones with and without metabolic abnormalities, thiazide use decreases urinary calcium and decreases stone recurrence. . $^{89-96}$

Dosages used in clinical trials are hydrochlorothiazide (25 mg orally, twice daily; 50mg orally, once daily), chlorthalidone (25 mg orally, once daily), and indapamide (2.5 mg orally, once daily). The dose-dependent side effects of thiazide diuretics include hypokalemia, hyperglycemia, hyperlipidemia, hyperuricemia, hypomagnesemia, and hypocitraturia. Combining thiazide diuretics with potassium citrate or potassium chloride prevents hypokalemia and hypochloremic metabolic alkalosis..$^{97,98}$

Thiazides have been demonstrated in clinical trials to decrease urinary calcium and decrease the rate of stone recurrence in calcium stone-forming patients (Level of Evidence 1-3, Grade A-B Recommendation).

\section{Alkali citrate}

Alkali citrate (potassium citrate, potassium magnesium citrate, sodium citrate, etc.) have been analyzed in several studies for prevention of nephrolithiasis. Alkali citrate results in a significant increase in urinary $\mathrm{pH}$ and urinary citrate and decreases recurrent nephrolithiasis. ${ }^{99-107}$ Potassium citrate is the most commonly studied agent, with dosages in clinical trials ranging from $30-60 \mathrm{mEq}$ in divided doses daily. Given the risk of calcium phosphate stone formation with the use of citrate, careful monitoring of urine $\mathrm{pH}$ is recommended. Gastrointestinal upset is the primary side effect. Hyperkalemia may occur in patients with renal insufficiency. In this situation, treatment with sodium-based alkali (sodium citrate, sodium bicarbonate) is an alternative. Overall, potassium citrate is preferred over sodium citrate, as the sodium load may increase urinary calcium excretion. ${ }^{108}$

Alkali citrates are effective in increasing urinary citrate, urinary $p H$, and reducing stone recurrence in calcium stone-formers (Level of Evidence 1-3, Grade A-B Recommendation).

\section{Allopurinol}

Studies regarding hyperuricosuria in calcium oxalate stone disease show mixed results. In a large cross-sectional study of stone-forming patients, urinary uric acid levels were not associated with increased risk for calcium oxalate stone formation. ${ }^{109}$ However, in a double-blind study of allopurinol in

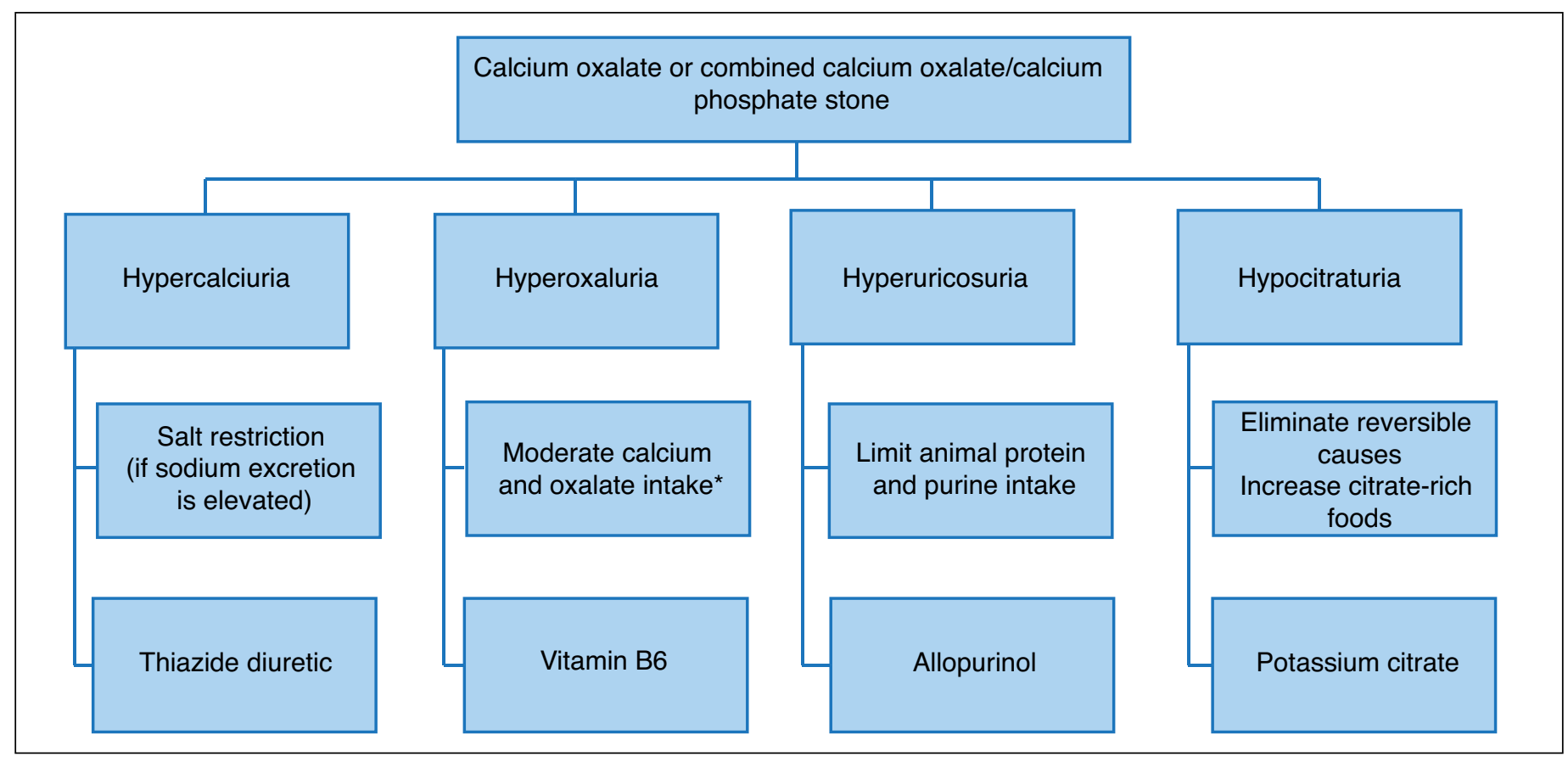

Fig. 1. Specific dietary and medical treatments for patients with calcium oxalate or mixed calcium oxalate/calcium phosphate stones. ${ }^{*}$ Calcium intake $1200 \mathrm{mg}$ daily (with meals), moderation of foods high in oxalate, pair oxalate and calcium-containing foods. 
prevention of calcium oxalate stones in patients with hyperuricosuria and normocalciuria, the allopurinol group had $81 \%$ fewer stones compared to placebo and a delayed time to stone recurrence. ${ }^{110}$ In a prospective, blinded, placebocontrol trial of allopurinol in patients with calcium oxalate stones and elevated uric acid levels (serum or urine), 92 patients were randomized and allopurinol was effective in reducing stone formation in $61 \%$ of individuals; ${ }^{111}$ however, on meta-analysis allopurinol was only beneficial in patients with hyperuricosuria. ${ }^{112}$

The typical allopurinol dosage is $200-300 \mathrm{mg}$ daily in single or divided doses. Major side effects include rash, gastrointestinal upset, abnormal liver enzyme levels, and prolonged elimination in renal disease. Febuxostat has been studied in the setting of calcium stones and hyperuricosuria. Despite greater reduction in 24-hour urinary uric acid level when compared to allopurinol, there was no change in stone size or number at six months. At this point, there is insufficient evidence to support its use in calcium stone patients. ${ }^{113}$

In patients with calcium oxalate stones, hyperuricosuria, and normocalciuria, allopurinol is effective in reducing stone recurrence. Allopurinol was not effective in prevention of nephrolithiasis in patients with normal urinary uric acid levels (Level of Evidence 1-2, Grade B Recommendation).

\section{Index patient 2: Pure calcium phosphate stone}

Patients who form pure calcium phosphate stones may have an underlying condition predisposing them to this type of stone formation, such as distal renal tubular acidosis, primary hyperparathyroidism, chronic urinary tract infection, hypercalciuria, and/or hyperphosphaturia.

Patients with primary hyperparathyroidism have a significantly increased risk of renal stone disease compared to controls. ${ }^{114,115}$ Even in patients with normal serum calcium levels, an elevated parathyroid hormone can increase kidney stone risk and result in decreased bone mineral density. ${ }^{116,117}$ Surgery for primary hyperparathyroidism results in decreased stone formation, a decrease in serum calcium, and an improvement of bone mineral density. ${ }^{118}$

Patients with distal renal tubular acidosis (dRTA) or medullary sponge kidney may present with recurrent apatite stones, nephrocalcinosis, systemic acidosis, osteoporosis, failure to thrive, or sensorineural hearing loss. ${ }^{119}$ Patients with dRTA generally have underlying hypocitraturia and are treated with alkali citrate. ${ }^{120,121}$ Potassium citrate has demonstrated superior effects on urinary indices as compared to sodium citrate in patients with incomplete dRTA. ${ }^{108}$ In patients with demonstrated dRTA treatment with $60-80 \mathrm{mEq}$ daily of potassium citrate resulted in increased urine $\mathrm{pH}$ and urine citrate, decreased urine calcium, and significantly reduced stone formation. ${ }^{122}$ When administered to patients with medullary sponge kidney, potassium citrate was associated with a rise in urinary citrate, a decrease in urinary calcium and a reduction in stone formation. ${ }^{123}$

Suggestive biochemical features of primary hyperparathyroidism and distal RTA are listed in Table 1.

Patients with recurrent urinary tract infection and calcium phosphate stone formation may have bacterial persistence of a urease-producing organism causing increased urine $\mathrm{pH}$ and brushite stone formation. Infection should be treated appropriately and stone material removed to avoid reinfection.

\section{Index patient 3: Uric acid stone}

Uric acid stone-formers are at significant risk of recurrence. Uric acid stones may form as the result of a number of underlying metabolic disorders, including obesity, metabolic syndrome, diabetes mellitus, gout, excessive bicarbonate loss due to high output bowel disease, myeloproliferative disorders, and tumour lysis syndrome..$^{5,124}$ In several studies, factors that increase the likelihood or risk of uric acid stones include older age, increased weight, increased serum uric acid level, decreased urinary calcium, and acidic urine. ${ }^{125-127}$ Uric acid stone formation is most commonly associated with low urinary $\mathrm{pH}$ and low urine volume rather than hyperuricosuria. ${ }^{109}$

Table 1. Characteristic findings, investigations, and treatment of primary hyperparathyroidism and distal renal tubular acidosis

\begin{tabular}{|c|c|c|c|}
\hline Disorder & Suggestive features & Investigations & Treatment \\
\hline Primary hyperparathyroidism & $\begin{array}{c}\uparrow \text { or } \uparrow N \text { serum calcium } \\
\uparrow \text { or } \uparrow N \text { serum PTH } \\
\text { Hypercalciuria } \\
\text { Calcium oxalate or calcium } \\
\text { phosphate stone } \\
\text { Decreased bone mineral density }\end{array}$ & Serum calcium, PTH, vitamin D & $\begin{array}{l}\text { Treat vitamin D deficiency } \\
\text { Referral to endocrinology }\end{array}$ \\
\hline Distal renal tubular acidosis & $\begin{array}{c}\text { Urine } \mathrm{pH}>5.8 \\
\downarrow \text { serum bicarbonate } \\
\downarrow \text { serum potassium } \\
\text { Pure apatite stone } \\
\text { Hypocitraturia }\end{array}$ & $\begin{array}{c}\text { Serum electrolytes } \\
\text { Urine } \mathrm{pH} \\
\text { Ammonium chloride load test* }\end{array}$ & Potassium citrate \\
\hline
\end{tabular}

*Optional; PTH: parathyroid hormone; $\uparrow:$ high; $\uparrow N$ : at the high end of normal range; $\downarrow$ : low. 


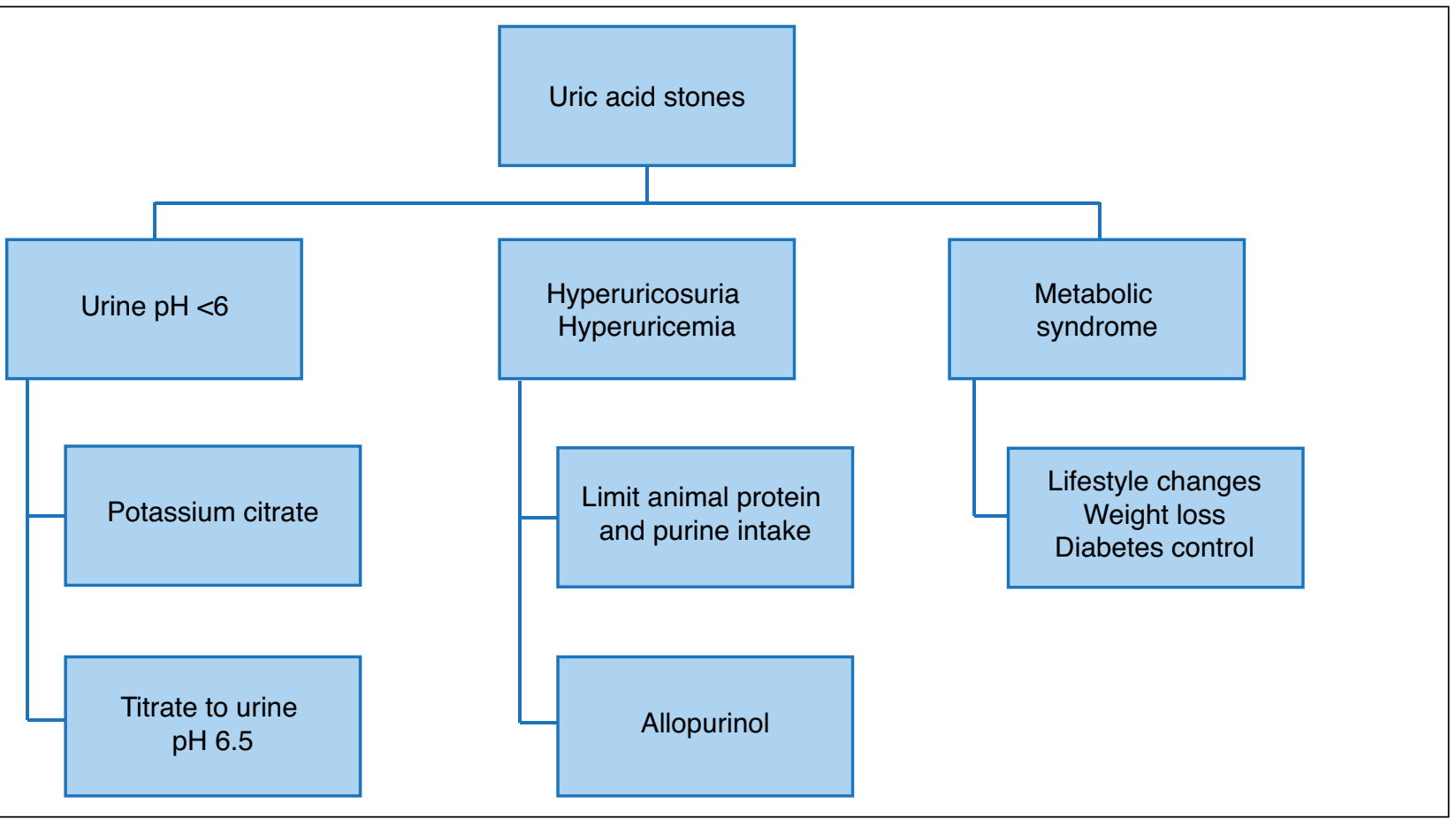

Fig. 2. Specific dietary and medical treatments for patients with uric acid stones.

Focus of treatment for uric acid stones should, therefore, primarily be to correct urine $\mathrm{pH}$ above 5.5 and increase urine volume rather than institute treatment of uric acid production. ${ }^{124}$ Excellent success with in situ stone dissolution has been demonstrated using potassium citrate. ${ }^{128,129}$

Many studies have now been published on metabolic syndrome and the risk of kidney stones (particularly uric acid stones). ${ }^{130}$ Furthermore, the association between metabolic syndrome and low urinary $\mathrm{pH}$ is well-established. ${ }^{127,131-133}$ The underlying insulin resistance in these patients leads to impaired glutamine metabolism, ammonia production, and ammonium excretion. This results in unbuffered hydrogen ions and a lowering of the urinary $\mathrm{pH} .{ }^{134}$ Based on the number of metabolic syndrome traits, the risk of stone formation may go up two-fold. ${ }^{135}$ Dietary and medical prophylaxis options are shown in Fig. 2.

In patients with uric acid stones, alkalinization of the urine targeting a urine $\mathrm{pH}$ of 6.5 is the first-line therapy. Allopurinol may be used as adjunctive therapy in patients with hyperuricemia or hyperuricosuria (Level of Evidence 1-3, Grade B Recommendation).

\section{Index patient 4: Cystine stone}

Cystinuria is a common genetic disorder affecting 1/7000 individuals. Cystine stone-formers often present in childhood or as teenagers and maybe plagued by recurrent stone formation and the need for repetitive surgical intervention, especially if prophylaxis is not optimized.
Patients with cystinuria should be encouraged to maintain a urine output of at least $3 \mathrm{~L}$ daily (often demanding oral intake of 3.5-4 $\mathrm{L}$ of fluid). This is a critical component of cystine stone management, as even with adjunctive medical therapy, the success of stone prevention will be poor in patients who do not comply with increased fluid intake. ${ }^{136,137}$ Sodium restriction is advised for all patients with cystinuria because sodium and cystine excretion are associated. ${ }^{138}$ In small studies, sodium restriction significantly decreased cystine excretion, ${ }^{138-140}$ reflecting this coupling of cystine to parallel sodium transport in the kidney. Elevated dietary protein is associated with increased urinary cystine ${ }^{141}$ and a reduction in overall protein intake can decrease urinary cystine levels.

The solubility of cystine increases significantly between urine $\mathrm{pH}$ of 7.0 to 7.5. Urinary alkalinization is, therefore, the initial step in medical therapy, with the goal of achieving a urine $\mathrm{pH}$ of greater than $7.0 .^{142} \mathrm{~A}$ urinary $\mathrm{pH}$ of greater than 7.5 , however, should be avoided, as this may promote calcium phosphate stone formation. Acetazolamide may be used as an adjunct to urinary alkalinization when potassium citrate alone is ineffective. ${ }^{143}$ If alkalizing agents fail to adequately control cystine stone formation, thiol binding agents, such as penicillamine 1-2 g or tiopronin $800-120$ Omg in daily divided doses, may be used. ${ }^{136,144-146}$ Side effects from penicillamine can be significant and include fever, arthralgias, rash, dysgeusia, leucopenia, and proteinuria. Tiopronin is not currently available in Canada. To monitor thiol drug therapy, urinary supersaturation of cystine or 


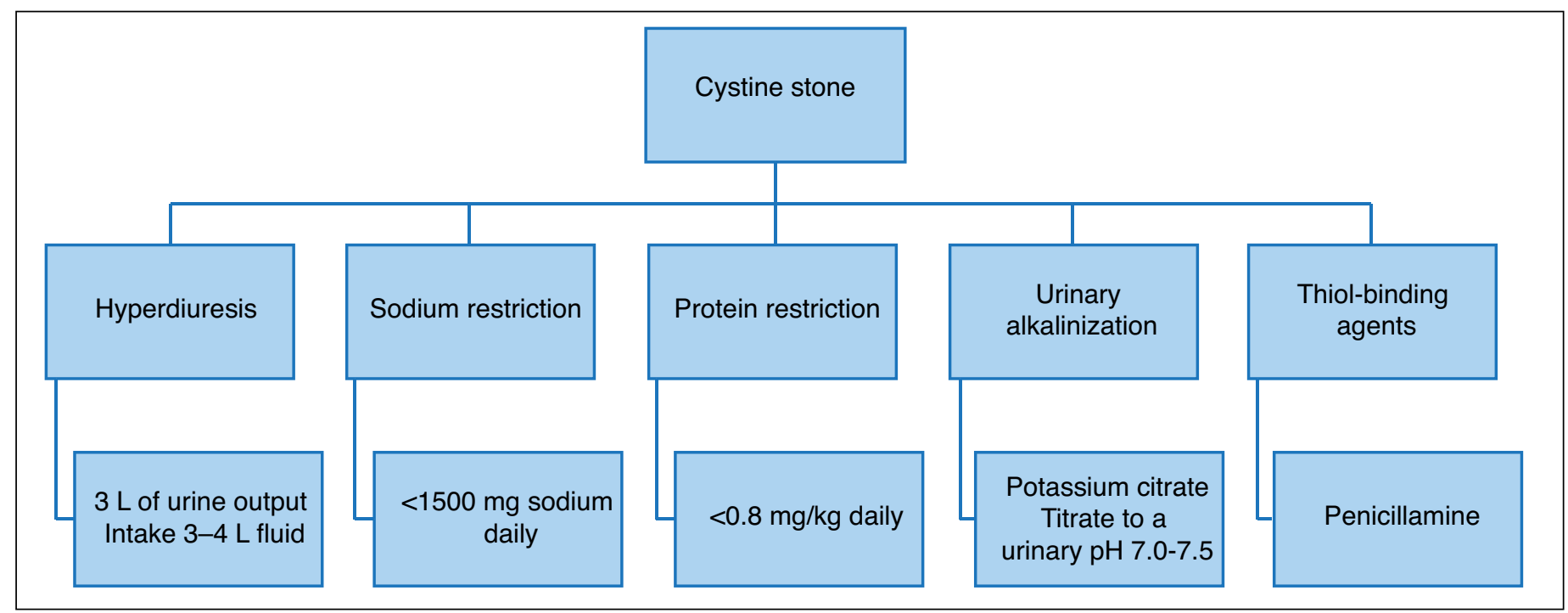

Fig. 3. Specific dietary and medical treatments for patients with cystine stones.

cystine capacity may be monitored and used to determine minimum effective dosage for individual patients. ${ }^{147,148}$ In a small study, captopril was compared to fluid and alkalinization in prevention of cystine stones. Stone formation was reduced, but significance was not achieved and captopril is not currently recommended for cystine stone prevention. ${ }^{149}$ Dietary and medical prevention options are shown in Fig. 3.

Long-term compliance in patients with cystinuria can be difficult to achieve $\mathrm{e}^{150}$ and consideration should be given to management of these patients at specialized clinics and close followup continued until disease stability is achieved.

In patients with cystine stones, alkalinization of the urine targeting a urine $\mathrm{pH}$ of $7-7.5$ is the initial therapy. Thiolbinding agents should be considered second-line therapy (Level of Evidence 3-4, Grade C Recommendation).

\section{Index patient 5: Struvite stone}

While strictly speaking, struvite stone formation is not considered a metabolic condition, medical therapy can have a role to play in prevention. Struvite stones occur as a consequence of urinary infection with urease-producing organisms. Surgical removal of stone material is the standard therapy. Whenever possible, foreign bodies, such as urinary stents or catheters, should be removed. The urease inhibitor acetohydroxamic acid (AHA) has been studied with limited success and not insignificant side effects. ${ }^{151-153}$ This agent is not currently available in Canada. A better-tolerated prevention strategy may be low-dose suppressive antibiotic therapy, but the risk of bacterial resistance should be taken into consideration. ${ }^{154,155}$

\section{Summary}

For patients at risk of recurrent renal stones, a detailed medical evaluation and an individualized approach to dietary and pharmacological prevention are important aspects of their care. The frequency of followup and the need for repeat metabolic testing is not clearly defined in the literature and must, therefore, also be individualized. In patients where specific medical prophylaxis has been prescribed, reevaluations with repeat metabolic testing within six months and yearly thereafter to monitor treatment efficacy and side effects are recommended. ${ }^{15}$ Periodic imaging is also recommended for those harbouring small asymptomatic stones.

Urologists, in addition to providing state-of-the-art surgical care to our patients, should be capable of providing up-todate metabolic assessment and optimal prevention strategies as part of a comprehensive approach to stone management.

Competing interests: Dr. Chew has been an advisor for Boston Scientific, Cook Medical, Olympus, Poly-Med, Advatec Inc., and PercSys Inc; and has participated in clinical trials with Poly-Med Inc., and Advatec Inc. Dr. Razvi has been an advisor for Histosonics and a speaker for Olympus. The remaining authors report no competing personal or financial interests.

This paper has been peer-reviewed.

\section{References}

1. Scales CD Jr, Smith AC, Hanley JM, et al. Prevalence of kidney stones in the United States. Eur Urol 2012;62:160-5. http://dx.doi.org/10.1016/i.eururo.2012.03.052

2. Stamatelou KK, Francis ME, Jones $C A$, et al. Time trends in reported prevalence of kidney stones in the United States. Kidney Int 2003;63:1817-23. http://dx.doi.org/10.1046/j.1523-1755.2003.00917.x

3. Penniston KL, McLaren ID, Greenlee RT, et al. Urolithiasis in a rural Wisconsin population from 1992 to 2008: Narrowing of the male-to-female ratio. J Urol 201 1;185:1731-6. http://dx.doi.org/10.1016/i. juro.2010.12.034 
Dion et al.

4. Scales CD Jr, Curtis LH, Norris RD, et al. Changing gender prevalence of stone disease. J Urol 2007;177:979-82. http://dx.doi.org/10.1016/i.juro.2006.10.069

5. Chou YH, Su CM, Li CC, et al. Difference in urinary stone components between obese and non-obese patients. Urol Res 201 1;39:283-7. httrp://dx.doi.org/10.1007/s00240-010-0344-8

6. Uribarri J, Oh MS, Carroll HJ. The first kidney stones. Ann Intern Med 1989;111:1006-9. http://dx.doi. org/10.7326/0003-4819-111-12-1006

7. Rule AD, Lieske JC, Li X, et al. The ROKS nomogram for predicting a second symptomatic stone episode. J Amer Soc Nephrol 2014;25:2685-7. http://dx.doi.org/10.1681/ASN.2013091011

8. Bensalah K, Tuncel A, Raman JD, et al. How physician and patient perceptions differ regarding medical management of stone disease. J Urol 2009;182:998-1004. http://dx.doi.org/10.1016/i. juro.2009.05.025

9. Milose JC, Kaufman SR, Hollenbeck BK, et al. Prevalence of 24-hour urine collection in high-risk stone formers. J Urol 2014;191:376-80. http://dx.doi.org/10.1016/i.juro.2013.08.080

10. Saigal CS, Joyce G, Timilsina AR, et al. Direct and indirect costs of nephrolithiasis in an employed population: Opportunity for disease management? Kidney Int 2005;68:1808-14. http://dx.doi. org/10.1111/.1.1523-1755.2005.00599.x

11. Pearle MS, Calhoun EA, Curhan GC, et al. Urologic diseases in America project: Urolithiasis. I Urol 2005; 173:848-57. http://dx.doi.org/10.1097/01.ju.0000152082.14384.d7

12. Eaton SH, Cashy J, Pearl JA, et al. Admission rates and costs associated with emergency presentation of urolithiasis: Analysis of the Nationwide Emergency Department Sample 2006 2009. J Endourol 2013;27:1535-8. http://dx.doi.org/10.1089/end.2013.0205

13. Antonelli JA, Maalouf NM, Pearle MS, et al. Use of the National Health and Nutrition Examination Survey to calculate the impact of obesity and diabetes on cost and prevalence of urolithiasis in 2030. Eur Urol 2014;66:724-9. http://dx.doi.org/10.1016/j.eururo.2014.06.036

14. Skolarikos A, Straub M, Knoll T, et al. Metabolic evaluation and recurrence prevention for urinary stone patients: EAU guidelines. Eur Urol 2015;67:750-63. http://dx.doi.org/10.1016/i.eururo.2014.10.029

15. Pearle MS, Goldfarb DS, Assimos DG, et al. American Urological Association. Medical management of kidney stones: AUA guideline. J Urol 2014;192:316-24. http://dx.doi.org/10.1016/i.juro.2014.05.006

16. Goldfarb DS, Arowojolu 0. Metabolic evaluation of first-time and recurrent stone formers. Urol Clin North Am 2013;40:13-20. http://dx.doi.org/10.1016/i.ucl.2012.09.007

17. Maalouf N. Approach to the adult kidney stone-former. Clin Rev Bone Miner Metab 2012;10:38-49 http://dx.doi.org/10.1007/s12018-011-9111-9

18. Kadlec A0, Turk TM. Update on the evaluation of repeated stone-formers. Curr Urol Rep 2013;14:549-56 http://dx.doi.org/10.1007/s11934-013-0347-4

19. Eisner $\mathrm{BH}$, Sheth S, Dretter SP, et al. Abnormalities of 24-hour urine composition in first-time and recurrent stone-formers. Urology 2012;80:776-9. http://dx.doi.org/10.1016/i.urology.2012.06.034

20. Koyuncu HH, Yencilek F, Eryildirim B, et al. Family history in stone disease: How important is it for the onset of the disease and the incidence of recurrence? Urol Res 2010;38:105-9. http://dx.doi. org/10.1007/s00240-009-0249-6

21. Pak CY, Peterson R, Poindexter JR. Adequacy of a single stone risk analysis in the medical evaluation of urolithiasis. J Urol 2001;165:378-81. http://dx.doi.org/10.1097/00005392-200102000-00006

22. Parks JH, Goldfisher E, Asplin JR, et al. A single 24-hour urine collection is inadequate for the medical evaluation of nephrolithiasis. J Urol 2002;167:1607-12. http://dx.doi.org/10.1016/S00225347(05)65163-4

23. Healy KA, Hubosky SG, Bagley DH. 24-hour urine collection in the metabolic evaluation of stone formers: Is one study adequate? J Endourol 2013;27:374-8. http://dx.doi.org/10.1089/end.2012.0216

24. Nayan M, Elkoushy MA, Andonian S. Variations between two 24-hour urine collections in patients presenting to a tertiary stone clinic. Can Urol Assoc J 2012;6:30-3

25. Lee $\Pi$, Elkoushy MA, Andonian $S$. Are stone analysis results different with repeated sampling? Can Urol Assoc J 2014;8:E317-22. http://dx.doi.org/10.5489/cuaj.1872

26. Hosking DH, Erickson SB, Van den Berg CJ, et al. The stone clinic effect in patients with idiopathic calcium urolithiasis. J Urol 1983;130:1115-8.

27. Ortiz-Alvarado 0, Miyaoka R, Kriedberg C, et al. Impact of dietary counselling on urinary stone risk parameters in recurrent stone-formers. J Endourol 2011;25:535-40. http://dx.doi.org/10.1089/ end.2010.0241

28. Penniston KL. The nutrition consult for recurrent stone-formers. Curr Urol Rep 2015;16:47. http://dx.doi. org/10.1007/s1 1934-015-0518-6

29. Damasio PC, Amaro CR, Padovani CR, et al. Influence of clinical therapy and nutritional counselling on the recurrence of urolithiasis. Acta Cir Bras 2014;29:400-4. http://dx.doi.org/10.1590/S0102 86502014000600009

30. Kocvara R, Plasqura P, Petrik A, et al. A prospective study of nonmedical prophylaxis after a first kidney stone. BJU Int 1999;84:393-8. http://dx.doi.org/10.1046/j.1464-410x.1999.00216.x

31. Sorensen MD, Kahn AJ, Reiner AP, et al. Impact of nutritional factors on incident kidney stone formation: A report from the WHI OS. J Urol 2012;187:1645-9. hittp://dx.doi.org/10.1016/i.juro.2011.12.077
32. Curhan GC, Willett WC, Rimm EB, et al. A prospective study of dietary calcium and other nutrients and the risk of symptomatic kidney stones. N Engl J Med 1993;328:833-8. http://dx.doi.org/10.1056/ NEJM199303253281203

33. Curhan GC, Willett WC, Speizer FE, et al. Comparison of dietary calcium with supplemental calcium and other nutrients as factors affecting the risk for kidney stones in women. Ann Intern Med 1997;126:497504. http://dx.doi.org/10.7326/0003-4819-126-7-199704010-00001

34. Curhan GC, Willett WC, Knight EL, et al. Dietary factors and the risk of incident kidney stones in younger women: Nurses' Health Study II. Arch Intern Med 2004;164:885-91. http://dx.doi.org/10.1001/ archinte.164.8.885

35. Ferraro PM, Taylor EN, Gambaro G, et al. Soda and other beverages and the risk of kidney stones. Clin J Am Soc Nephrol 2013;8:1389-95. http://dx.doi.org/10.2215/CJN.11661112

36. Cheungpasitporn W, Rossetti S, Friend K, et al. Treatment effect, adherence, and safety of high fluid intake for the prevention of incident and recurrent kidney stones: A systematic review and meta-analysis. J Nephrol 2016;29:211-9. http://dx.doi.org/10.1007/s40620-015-0210-4

37. Borghi L, Meschi T, Maggiore U, et al. Dietary therapy in idiopathic nephrolithiasis. Nutr Rev 2006;64:30112. http://dx.doi.org/10.1111/i.1753-4887.2006.tb00214.x

38. Fink HA, Akornor JW, Garimella PS, et al. Diet, fluid, or supplements for secondary prevention of nephrolithiasis: A systematic review and meta-analysis of randomized trials. Eur Urol 2009;56:72-80. http:// dx.doi.org/10.1016/j.eururo.2009.03.031

39. Borghi L, Meschi T, Amato F, et al. Urinary volume, water, and recurrences in idiopathic calcium nephrolithiasis: A 5-year randomized, prospective study. J Urol 1996;155:839-43. http://dx.doi.org/10.1016/ S0022-5347(01)66321-3

40. Sarica $K$, Inal $Y$, Erturhan $S$, et al. The effect of calcium channel blockers on stone regrowth and recurrence after shockwave lithotripsy. Urol Res 2006;34:184-9. http://dx.doi.org/10.1007/s00240-006-0040-x

41. Sawyer MD, Anderson CB, Viprakasit DP, et al. An individualized weight-based goal urine volume model significantly improves expected calcium concentrations relative to a $2-\mathrm{L}$ goal urine volume. Urolithiasis 2013;41:403-9. http://dx.doi.org/10.1007/s00240-013-0573-8

42. Herrel L, Pattaras J, Solomon T, et al. Urinary stone risk and cola consumption. Urology 2012;80:990-4. http://dx.doi.org/10.1016/j.urology.2012.07.003

43. Shuster J, Jenkins A, Logan C, et al. Soft drink consumption and urinary stone recurrence: A randomized prevention trial. J Clin Epidemiol 1992;45:911-6. http://dx.doi.org/10.1016/0895-4356(92)90074-W

44. Wang $X, X \cup X$, Wu J, et al. Systematic review and meta-analysis of the effect of alcohol intake on the risk of urolithiasis including dose-response relationship. Urol Int 2015;94:194-204. http://dx.doi. org/10.1159/000365358

45. Ferraro PM, Taylor EN, Gambaro G, et al. Caffeine intake and the risk of kidney stones. Am I Clin Nutr 2014;100:1596-603. http://dx.doi.org/10.3945/aicn.114.089987

46. Ferraro PM, Taylor EN, Gambaro G, et al. Soda and other beverages and the risk of kidney stones. Clin J Am Soc Nephrol 2013;8:1389-95. http://dx.doi.org/10.2215/CJN.11661112

47. Wang $S$, Zhang $Y$, Mao $Z$, et al. A meta-analysis of coffee intake and risk of urolithiasis. Urol Int 2014;93:220-8. http://dx.doi.org/10.1159/000356559

48. Penniston KL, Steele TH, Nakada SY. Lemonade therapy increases urinary citrate and urine volumes in patients with recurrent calcium oxalate stone formation. Urology 2007;70:856-60. http://dx.doi. org/10.1016/i.urology.2007.06.1115

49. McCauley LR, Dyer AJ, Stern K, et al. Factors influencing fluid intake behaviour among kidney stone formers. J Urol 2012;187:1282-6. http://dx.doi.org/10.1016/i.juro.2011.11.111

50. Taylor EN, Stampfer MJ, Curhan GC. Dietary factors and the risk of incident kidney stones in men: New insights after 14 years of followup. J Am Soc Nephrol 2004;15:3225-32. http://dx.doi. org/10.1097/01.ASN.0000146012.44570.20

51. Radford LT, Bolland MJ, Mason B, et al. The Auckland calcium study: 5-year post-trial followup. Osteoporos Int 2014;25:297-304. http://dx.doi.org/10.1007/s00198-013-2526-z

52. Penniston KL, Nakada SY. Effect of dietary changes on urinary oxalate excretion and calcium oxalate supersaturation in patients with hyperoxaluric stone formation. Urology 2009;73:484-9. http://dx.doi. org/10.1016/i.urology.2008.10.035

53. Straub DA. Calcium supplementation in clinical practice: A review of forms, doses, and indications. Nutr Clin Pract 2007;22:286-96. http://dx.doi.org/10.1177/0115426507022003286

54. Reinwald S, Weaver CM, Kester JJ. The health benefits of calcium citrate malate: A review of the supporting science. Adv Food Nutr Res 2008;54:219-346. http://dx.doi.org/10.1016/S1043-4526(07)00006-X

55. Liebman M, Chai W. Effect of dietary calcium on urinary oxalate excretion after oxalate loads. Am I Clin Nutr 1997;65:1453-9.

56. Elkoushy MA, Sabbagh R, Unikowsky B, et al. Prevalence and metabolic abnormalities of vitamin D-inadequate patients presenting with urolithiasis to a tertiary stone clinic. Urology 2012;79:781-5. http://dx.doi.org/10.1016/i.urology.2011.09.004

57. Pipili C, Oreopoulos DG. Vitamin D status in patients with recurrent kidney stones. Nephron Clin Pract 2012;122:134-8. http://dx.doi.org/10.1159/000351377 
58. Tsuï H, Umekawa T, Kurita T, et al. Analysis of bone mineral density in urolithiasis patients. Int I Urol 2005;12:335-9. http://dx.doi.org/10.1111/i.1442-2042.2005.01049.x

59. Tugcu $V$, Ozbek E, Aras B, et al. Bone mineral density measurement in patients with recurrent normocalciuric calcium stone disease. Urol Res 2007;35:29-34. http://dx.doi.org/10.1007/s00240-006-0074-0

60. Letavernier $\mathrm{E}$, Traxer 0 , Daudon $\mathrm{M}$, et al. Determinants of osteopenia in male renal-stone-disease patients with idiopathic hypercalciuria. Clin J Am Soc Nephrol 201 1;6:1149-54. http://dx.doi.org/10.2215/ CJN. 10191110

61. Denburg MR, Leonard MB, Haynes K, et al. Risk of fracture in urolithiasis: A population-based cohort study using the health improvement network. Clin J Am Soc Nephrol 2014:9:2133-40. http://dx.doi. org/10.2215/CJN.04340514

62. Elkoushy $M A$, Jundi $M$, Lee $\Pi$, et al. Bone mineral density status in urolithiasis patients with vitamin D inadequacy followed at a tertiary stone centre. Can Urol Assoc J 2014;8:323-8. http://dx.doi. org/10.5489/cuaj.2055

63. Pasch A, Frey FJ, Eisenberger $\mathrm{U}$, et al. PTH and 1.25-vitamin D response to a low-calcium diet is associated with bone mineral density in renal stone-formers. Nephrol Dial Transplant 2008;23:2563-70. http:// dx.doi.org/10.1093/ndt/gfn091

64. Rathod A, Bonny 0 , Guessous I, et al. Association of urinary calcium excretion with serum calcium and vitamin D levels. Clin J Am Soc Nephrol 2015;10:452-62. http://dx.doi.org/10.2215/CJN.12511213

65. Eisner BH, Thavaseelan $S$, Sheth $S$, et al. Relationship between serum vitamin $D$ and 24-hour urine calcium in patients with nephrolithiasis. Urology 2012;80:1007-10. http://dx.doi.org/10.1016/i. urology.2012.04.041

66. Nguyen S, Baggerly L, French C, et al. 25-hydroxyvitamin D in the range of $20100 \mathrm{ng} / \mathrm{mL}$ and incidence of kidney stones. Am J Public Health 2014;104:1783-7. http://dx.doi.org/10.2105/AJPH.2013.301368

67. Hesswani C, Noureldin YA, Elkoushy MA, et al. Combined vitamin D and calcium supplementation in vitamin D inadequate patients with urolithiasis: Impact on hypercalciuria and de novo stone formation. Can Urol Assoc J 2015;9:403-8. http://dx.doi.org/10.5489/cuaj.3332

68. Jackson RD, LaCroix AZ, Gass M. Calcium plus vitamin D supplementation and the risk of fractures. N Engl J Med 2006;354:669-83. http://dx.doi.org/10.1056/NEJMoa055218

69. Penniston KL, Jones AN, Nakada SY, et al. Vitamin D repletion does not alter urinary calcium excretion in healthy post-menopausal women. BJU Int 2009;104:1512-6. http://dx.doi.org/10.1111/i.1464410X.2009.08559.x

70. Nygaard B, Frandsen NE, Brandi L, et al. Effects of high doses of cholecalciferol in normal subjects: A randomized, double-blinded, placebo-controlled trial. PLoS One 2014;9:e102965. http://dx.doi. org/10.1371/journal.pone.0102965

71. Gallagher JC, Smith LM, Yalamanchili V. Incidence of hypercalciuria and hypercalcemia during vitamin D and calcium supplementation in older women. Menopause 2014;21:1173-80. http://dx.doi.org/10.1097/ GME.0000000000000270

72. Leaf $\mathrm{DE}$, Korets $\mathrm{R}$, Taylor $\mathrm{EN}$, et al. Effect of vitamin $\mathrm{D}$ repletion on urinary calcium excretion among kidney stone-formers. Clin J Am Soc Nephrol 2012;7:829-34. http://dx.doi.org/10.2215/CJN.11331111

73. Haghighi A, Samimagham H, Gohardehi G. Calcium and vitamin D supplementation and risk of kidney stone formation in postmenopausal women. Iran J Kidney Dis 2013;7:210-3.

74. Borghi L, Schianchi T, Meschi T, et al. Comparison of two diets for the prevention of recurrent stones in idiopathic hypercalciuria. N Engl J Med 2002;346:77-84. http://dx.doi.org/10.1056/NEJMoo010369

75. Trinchieri A, Mandressi A, Luongo $P$, et al. The influence of diet on urinary risk factors for stones in healthy subjects and idiopathic renal calcium stone-formers. Br I Urol 1991;67:230-6. http://dx.doi. org/10.1111/j.1464-410X.1991.tb15124.x

76. Trinchieri $A$, Lizzano $R$, Marchesotti $F$, et al. Effect of potential renal acid load of foods on urinary citrate excretion in calcium renal stone-formers. Urol Res 2006;34:1-7. http://dx.doi.org/10.1007/ s00240-005-0001-9

77. Hiatt RA, Ettinger B, Caan B, et al. Randomized, controlled trial of a low-animal protein, high-fiber dief in the prevention of recurrent calcium oxalate kidney stones. Am J Epidemiol 1996; 144:25-33. http:// dx.doi.org/10.1093/oxfordjournals.aje.a008851

78. Breslau NA, Brinkley L, Hill KD, et al. Relationship of animal protein-rich diet to kidney stone formation and calcium metabolism. J Clin Endocrinol Metab 1988;66:140-6. http://dx.doi.org/10.1210/ jcem-66-1-140

79. Siener R, Hesse A. The effect of a vegetarian and different omnivorous diets on urinary risk factors for uric acid stone formation. Eur J Nutr 2003;42:332-7. http://dx.doi.org/10.1007/s00394-003-0428-0

80. Tracy $C R$, Best $S$, Bagrodia $A$, et al. Animal protein and the risk of kidney stones: A comparative metabolic study of animal protein sources. J Urol 2014;192:137-41. http://dx.doi.org/10.1016/i. juro.2014.01.093

81. Damasio PC, Amaro CR, Cunha NB, et al. The role of salt abuse on risk for hypercalciuria. Nutr J 201 1;10:3. http://dx.doi.org/10.1186/1475-2891-10-3
82. Nouvenne A, Meschi T, Prati B, et al. Effects of a low-salt diet on idiopathic hypercalciuria in calciumoxalate stone formers: A 3-month, randomized, controlled trial. AJCN 2010;91:565-70. http://dx.doi. org/10.3945/ajcn.2009.28614

83. Sorensen MD, Hsi RS, Chi T, et al. Dietary intake of fiber, fruit and vegetables decreases the risk of incident kidney stones in women: A Women's Health Initiative report. J Urol 2014;192:1694-9. http:// dx.doi.org/10.1016/i.juro.2014.05.086

84. Yasui T, Okada A, Hamamoto $\mathrm{S}$, et al. The association between the incidence of urolithiasis and nutrition based on Japanese National Health and Nutrition Surveys. Urolithiasis 2013;41:217-24. http://dx.doi. org/10.1007/s00240-013-0567-6

85. Meschi T, Maggiore U, Fiaccadori E, et al. The effect of fruits and vegetables on urinary stone risk factors. Kidney Int 2004;66:2402-10. http://dx.doi.org/10.1111/i.1523-1755.2004.66029.x

86. Baxmann $A C$, De OG Mendonca C, Heilberg IP. Effect of vitamin C supplements on urinary oxalate and pH in calcium stone-forming patients. Kidney Int 2003;63:1066. http://dx.doi.org/10.1046/i.15231755.2003.00815.x

87. Traxer 0 , Huet $B$, Poindexter J, et al. Effect of ascorbic acid consumption on urinary stone risk factors. $J$ Urol 2003;170:397-401. http://dx.doi.org/10.1097/01.ju.0000076001.21606.53

88. Parvin $M$, Shakhssalim N, Basiri A, et al. The most important metabolic risk factors in recurrent urinary stone-formers. Urol J 2011;8:99-106.

89. Ohkawa $M$, Tokunaga $S$, Nakashima $T$, et al. Thiazide treatment for calcium urolithiasis in patients with idiopathic hypercalciuria. Br J Urol 1992:69:571-6. http://dx.doi.org/10.1111/i.1464-410X.1992.tb15624.x

90. Coe FL. Treated and untreated recurrent calcium nephrolithiasis in patients with idiopathic hypercalciuria, hyperuricosuria, or no metabolic disorder. Ann Intern Med 1977;87:404-10. http://dx.doi. org/10.7326/0003-4819-87-4-404

91. Brocks $P$, Dahl $C$, Wolf $H$, et al. Do thiazides prevent recurrent idiopathic renal calcium stones? Lancet 1981;2:124-5. http://dx.doi.org/10.1016/S0140-6736(81)90302-0

92. Mortensen JT, Schultz A, Ostergaard AH. Thiazides in the prophylactic treatment of recurrent idiopathic kidney stones. Int Urol Nephrol 1986;18:265-9. http://dx.doi.org/10.1007/BF02082712

93. Laerum $S$, Larsen $S$. Thiazide prophylaxis of urolithiasis. A double-blind study in general practice. Acta Med Scand 1984;215:383-9. http://dx.doi.org/10.1111/i.0954-6820.1984.tb05023.x

94. Fernandez-Rodriguez A, Arrabal-Martin M, Garcia-Ruiz MJ, et al. The role of thiazides in the prophylaxis of recurrent calcium lithiasis. Actas Urol Esp 2006;30:305-9.

95. Borghi L, Meschi T, Guerra A, et al. Randomized, prospective study of a non-thiazide diuretic, indapamide, in preventing calcium stone recurrences. J Cardiovasc Pharmacol 1993;22:S78-86. http://dx.doi. org/10.1097/00005344-199312050-00014

96. Ettinger B, Citron JT, Livermore B, et al. Chlorthalidone reduces calcium oxalate calculous recurrence but magnesium hydroxide does not. J Urol 1988;139:679-84.

97. Nicar MJ, Peterson R, Pak CY. Use of potassium citrate as potassium supplement during thiazide therapy of calcium nephrolithiasis. J Urol 1984;131:430-3.

98. Odvina CV, Preminger GM, Lindberg JS, et al. Long-term combined treatment with thiazide and potassium citrate in nephrolithiasis does not lead to hypokalemia or hypochloremic metabolic alkalosis. Kidney Int 2003;63:240-7. http://dx.doi.org/10.1046/i.1523-1755.2003.00719.x

99. Allie-Hamdulay S, Rodgers AL. Prophylactic and therapeutic properties of a sodium citrate preparation in the management of calcium oxalate urolithiasis: Randomized, placebo-controlled trial. Urol Res 2005;33:11624. http://dx.doi.org/10.1007/s00240-005-0466-6

100. Reddy SV, Shaik AB, Bokkisam S. Effect of potassium magnesium citrate and vitamin B-6 prophylaxis for recurrent and multiple calcium oxalate and phosphate urolithiasis. Korean J Urol 2014;55:411-6. http://dx.doi.org/10.4111/kju.2014.55.6.411

101. Barcelo P, Wuhl O, Servitge I, et al. Randomized, double-blind study of potassium citrate in idiopathic hypocitraturic calcium nephrolithiasis. J Urol 1993;150:1761-4.

102. Hofbauer J, Hobarth K, Szabo N, et al. Alkali citrate prophylaxis in idiopathic recurrent calcium oxalate urolithiasis: A prospective, randomized study. Br J Urol 1994;73:362-5. http://dx.doi.org/10.1111/ i.1464-410X.1994.tb07597.x

103. Mattle D, Hess B. Preventive treatment of nephrolithiasis with alkali citrate — a critical review. Urol Res 2005;33:73-9. http://dx.doi.org/10.1007/s00240-005-0464-8

104. Ettinger B, Pak CY, Citron JT, et al. Potassium-magnesium citrate is an effective prophylaxis against recurrent calcium oxalate nephrolithiasis. J Urol 1997;158:2069-73. http://dx.doi.org/10.1016/ S0022-5347(01)68155-2

105. Robinson MR, Leitao VA, Haleblian GE, et al. Impact of long-term potassium citrate therapy on urinary profiles and recurrent stone formation. J Urol 2009;181:1145-50. http://dx.doi.org/10.1016/i.juro.2008.11.014

106. Lojanapiwat $B$, Tanthanuch $M$, Pripathanont $C$, et al. Alkaline citrate reduces stone recurrence and regrowth after shockwave lithotripsy and percutaneous nephrolithotomy. Int Braz J Urol 2011;37:611-6. http:// dx.doi.org/10.1590/S1677-55382011000500007 
Dion et al.

107. Soygür T, Akbay A, Küpeli S. Effect of potassium citrate therapy on stone recurrence and residual fragments after shockwave lithotripsy in lower caliceal calcium oxalate urolithiasis: A randomized, controlled trial. J Endourol 2002;16:149-52. http://dx.doi.org/10.1089/089277902753716098

108. Preminger GM, Sakhaee K, Pak CY. Alkali action on the urinary crystallization of calcium salts: Contrasting responses to sodium citrate and potassium citrate. J Urol 1988;139:240-2.

109. Curhan GC, Taylor EN. 24-h uric acid excretion and the risk of kidney stones. Kidney Int 2008;73:489-96. http://dx.doi.org/10.1038/si.ki.5002708

110. Ettinger B, Tang A, Citron JT, et al. Randomized trial of allopurinol in the prevention of calcium oxalate calculi. N Engl J Med 1986;315:1386-9. http://dx.doi.org/10.1056/NEJM198611273152204

111. Smith MJ. Placebo vs. allopurinol for renal calculi. J Urol 1977;1 17:690-2.

112. Pearle MS, Roehrborn CG, Pak CY. Meta-analysis of randomized trials for medical prevention of calcium oxalate nephrolithiasis. J Endourol 1999;13:679-85. http://dx.doi.org/10.1089/end.1999.13.679

113. Goldfarb DS, MacDonald PA, Gunawardhana L, et al. Randomized, controlled trial of febuxostat vs. allopurinol or placebo in individuals with higher urinary uric acid excretion and calcium stones. Clin J Am Soc Nephrol 2013;8:1960-7. http://dx.doi.org/10.2215/CJN.01760213

114. Suh JM, Cronan JJ, Monchik JM. Primary hyperparathyroidism: Is there an increased prevalence of renal stone disease? Am J Roentgenol 2008;191:908-11. http://dx.doi.org/10.2214/AJR.07.3160

115. Mollerup CL, Vestergaard P, Frakjær VG, et al. Risk of renal stone events in primary hyperparathyroidism before and after parathyroid surgery: controlled retrospective followup study. BMJ 2002;325:807. http:// dx.doi.org/10.1136/bmi.325.7368.807

116. Amaral LM, Queiroz DC, Marques TF, et al. Normocalcemic vs. hypercalcemic primary hyperparathyroidism: More stone than bone? J Osteoporos 2012;2012:128352.

117. Tuna $M M$, Call kan $M$, Ünal $M$, et al. Normocalcemic hyperparathyroidism is associated with complications similar to those of hypercalcemic hyperparathyroidism. J Bone Miner Metab 2016;34:331-5. http:// dx.doi.org/10.1007/s00774-015-0673-3

118. Silverberg SJ, Shane E, Jacobs TP, et al. A 10-year prospective study of primary hyperparathyroidism with or without parathyroid surgery. N Engl J Med 1999;341:1249-55. http://dx.doi.org/10.1056/ NEJM199910213411701

119. Ferraro PM, D'Addessi A, Gambaro $G$. When to suspect a genetic disorder in a patient with renal stones, and why. Nephrol Dial Transplant 2013;28:811-20. http://dx.doi.org/10.1093/ndt/gfs545

120. Sakhaee K, Alpern R, Poindexter J, et al. Citraturic response to oral citric acid load. J Urol 1992;147:975-6.

121. Domrongkitchaiporn S, Khositseth S, Stitchantrakul W, et al. Dosage of potassium citrate in the correction of urinary abnormalities in pediatric distal renal tubular acidosis patients. Am J Kidney Dis 2002;39:383-91. http://dx.doi.org/10.1053/ajkd.2002.30560

122. Preminger GM, Sakhaee K, Skurla C, et al. Prevention of recurrent calcium stone formation with potassium citrate therapy in patients with distal renal tubular acidosis. J Urol 1985;134:20-3.

123. Fabris $A$, Lupo $A$, Bernich $P$, et al. Long-term treatment with potassium citrate and renal stones in medullary sponge kidney. Clin J Am Soc Nephrol 2010;5:1663-8. http://dx.doi.org/10.2215/CJN.00220110

124. Cameron MA, Sakhaee K. Uric acid nephrolithiasis. Urol Clin North Am 2007;34:335-46. http://dx.doi. org/10.1016/i.ucl.2007.05.001

125. Reichard C, Gill BC, Sarkissian C, et al. 100\% uric acid stone-formers: What makes them different? Urology 2015;85:296-8. http://dx.doi.org/10.1016/j.urology.2014.10.029

126. Torricelli $\mathrm{FC}$, Brown R, Berto $\mathrm{FC}$, et al. Nomogram to predict uric acid kidney stones based on patient's age, BMI, and 24-hour urine profiles: A multicentre validation. Can Urol Assoc J 2015;9:E178-82. http:// dx.doi.org/10.5489/cuaj.2682

127. Negri AL, Spivacow R, Del Valle E, et al. Clinical and biochemical profile of patients with "pure" uric acid nephrolithiasis compared with "pure" calcium oxalate stone-formers. Urol Res 2007;35:247-51. http:// dx.doi.org/10.1007/s00240-007-0109-1

128. Trinchieri A, Esposito N, Castelnuovo C. Dissolution of radiolucent renal stones by oral alkalinization with potassium citrate/potassium bicarbonate. Arch Ital Urol Androl 2009;81:188-91.

129. Pak CY, Sakhaee K, Fuller C. Successful management of uric acid nephrolithiasis with potassium citrate. Kidney Int 1986;30:422-8. http://dx.doi.org/10.1038/ki.1986.201

130. Shavit L, Ferraro PM, Johri N, et al. Effect of being overweight on urinary metabolic risk factors for kidney stone formation. Nephrol Dial Transplant 2015;30:607-13. http://dx.doi.org/10.1093/ndt/gfu350

131. Maalouf NM, Cameron MA, Moe OW, et al. Low urine pH: A novel feature of the metabolic syndrome. Clin J Am Soc Nephrol 2007;2:883-8. http://dx.doi.org/10.2215/CJN.00670207
132. Taylor EN, Curhan GC. Body size and 24-hour urine composition. Am J Kidney Dis 2006:48:905-15. http://dx.doi.org/10.1053/i.ajkd.2006.09.004

133. Semins MJ, Shore AD, Makary MA, et al. The association of increasing body mass index and kidney stone disease. J Urol 2010;183:571-5. http://dx.doi.org/10.1016/i.juro.2009.09.085

134. Maalouf NM, Cameron MA, Moe OW, et al. Novel insights into the pathogenesis of uric acid nephrolithiasis. Curr Opin Nephrol Hypertens 2004;13:181-9. http://dx.doi.org/10.1097/00041552-20040300000006

135. West B, Luke A, Durazo-Arvizu RA, et al. Metabolic syndrome and self-reported history of kidney stones: The National Health and Nutrition Examination Survey (NHANES III) 1988-1994. Am J Kidney Dis 2008;51:741-7. http://dx.doi.org/10.1053/i.ajkd.2007.12.030

136. Barbey F, Joly D, Rieu P, et al. Medical treatment of cystinuria: Critical reappraisal of long-term results. J Urol 2000;163:1419-23. http://dx.doi.org/10.1016/S0022-5347(05)67633-1

137. Mattoo A, Goldfarb DS. Cystinuria. Semin Nephrol 2008;28:181-91. http://dx.doi.org/10.1016/i. semnephrol.2008.01.011

138. Rodriguez $L M$, Santos F, Malaga $S$, et al. Effect of low-sodium diet on urinary elimination of cystine in cystinuric children. Nephron 1995;71:416-8. http://dx.doi.org/10.1159/000188761

139. Lindell A, Denneberg T, Edholm E, et al. The effect of sodium intake on cystinuria with and without tiopronin treatment. Nephron 1995;71:407-15. http://dx.doi.org/10.1159/000188760

140. Norman RW, Manette WA. Dietary restriction of sodium as a means of reducing urinary cystine. J Urol 1990;143:1193-5.

141. Rodman JS, Blackburn P, Williams JJ, et al. The effect of dietary protein on cystine excretion in patients with cystinuria. Clin Nephrol 1984;22:273-8.

142. Claes DJ, Jackson E. Cystinuria: Mechanisms and management. Pediatr Nephrol 2012;27:2031-38. http://dx.doi.org/10.1007/s00467-011-2092-6

143. Sterret SP, Penniston KL, Wolf JS, et al. Acetazolamide is an effective adjunct for urinary alkalinization in patients with uric acid and cystine stone formation recalcitrant to potassium citrate. Urology 2008;72:27881. http://dx.doi.org/10.1016/j.urology.2008.04.003

144. Dahlberg PJ, van den Berg, Kurtz SB, et al. Clinical features and management of cystinuria. Mayo Clin Proc 1977;52:533-42.

145. Pak CY, Fuller C, Sakhaee K, et al. Management of cystine nephrolithiasis with alpha-mercaptopropionylglycine. J Urol 1986;136:1003-8.

146. Chow GK, Streem SB. Medical treatment of cystinuria: Results of contemporary clinical practice. J Urol 1996;156:1576-8. http://dx.doi.org/10.1016/S0022-5347(01)65451-X

147. Dolin DJ, Asplin JR, Flagel L, et al. Effect of cystine-binding thiol drugs on urinary cystine capacity in patients with cystinuria. J Endourol 2005;19:429-32. http://dx.doi.org/10.1089/end.2005.19.429

148. Goldfarb DS, Coe FL, Asplin JR. Urinary cystine excretion and capacity in patients with cystinuria. Kidney Int 2006;69:1041-7. http://dx.doi.org/10.1038/si.ki.5000104

149. Cohen TD, Streem SB, Hall P. Clinical effect of captopril on the formation and growth of cystine calculi. J Urol 1995;154:164-6. http://dx.doi.org/10.1016/S0022-5347(01)67256-2

150. Pietrow PK, Auge BK, Weizer AZ, et al. Durability of the medical management of cystinuria. J Urol 2003;169:68-70. http://dx.doi.org/10.1016/S0022-5347(05)64037-2

151. Griffith DP, Khonsari F, Skurnick JH, et al. A randomized trial of acetohydroxamic acid for the treatment and prevention of infection-induced urinary stones in spinal cord injury patients. J Urol 1988; 140:318-24.

152. Griffith DP, Gleeson MJ, Lee $\mathrm{H}$, et al. Randomized, double-blind trial of Lithostat (acetohydroxamic acid) in the palliative treatment of infection-induced urinary calculi. Eur Urol 1991;20:243-7.

153. Williams JJ, Rodman JS, Peterson CM. A randomized, double-blind study of acetohydroxamic acid in struvite nephrolithiasis. N Engl J Med 1984;311:760-4. http://dx.doi.org/10.1056/NEJM198409203111203

154. Flannigan R, Choy WH, Chew B. Renal struvite stones - pathogenesis, microbiology, and management strategies. Nat Rev Urol 2014;11:333-41. http://dx.doi.org/10.1038/nrurol.2014.99

155. Zanetti G, Paparella S, Trinchieri A. Infections and urolithiasis: Current clinical evidence in prophylaxis and antibiotic therapy. Arch Ital Urol Androl 2008;80:5-12.

Correspondence: Dr. Hasan Razvi, Division of Urology, Schulich School of Medicine and Dentistry, Western University, London, ON, Canada; Hassan.Razvi@sihc.london.on.ca 